\title{
Potentiality of Extracts of Medicinal Plants against Important Plant Pathogenic Bacteria
}

\author{
N. Kiran Kumar ${ }^{1 *}$, V. B. Sanath Kumar ${ }^{1}$, H. R. Raveendra ${ }^{2}$ and S. E. Manjunatha ${ }^{1}$ \\ ${ }^{1}$ Department of Plant Pathology, College of Agriculture, V.C. Farm, Mandya, Karnataka, India \\ ${ }^{2}$ Pathologist, AICRP (Millets) ZARS, V.C. Farm, Mandya, Karnataka, India \\ ${ }^{3}$ College of Agriculture, V.C. Farm, Mandya, Karnataka, India \\ *Corresponding author
}

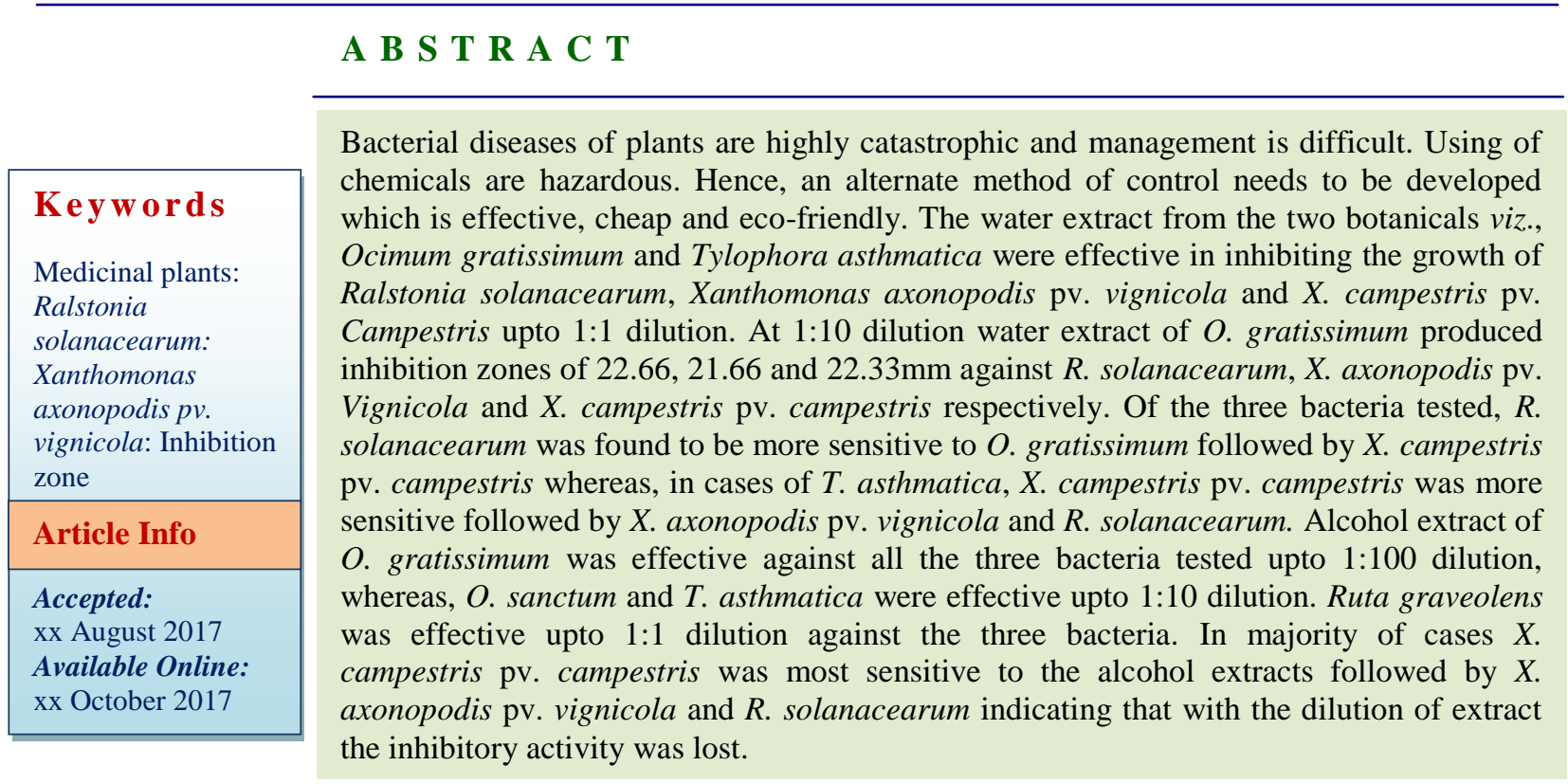

\section{Introduction}

Among the diseases of agricultural and horticultural crops, diseases caused by bacteria are usually very difficult to control. Frequently a combination of different methods of control is required to combat a given bacterial disease. Also, use of chemicals to control bacterial diseases has not been much successful as compared to the control of fungal diseases. The use of copper based bactericides seldom gave satisfactory control. Antibiotics used in the control have no doubt been successful in controlling the disease, however, use of antibiotics have certain drawbacks such as its prohibition cost, quick break down in nature, residual toxicity because of its systemic nature and more importantly quick development of resistance to the antibiotics by the bacterial pathogens. Botanicals because of their natural origin are biodegradable and they do not leave toxic residues or by-products to accumulate in the environment. Several plants have thousands years of history and the non-toxicity at least at oral level is proved. Further, the research and development cost of botanical pesticides from discovery to marketing is much less compared to chemical pesticides. Therefore under this scenario, botanical pesticides seem to be ideal candidate to be exploited in management of bacterial diseases in view of the safety, renewable nature, cost effective and high target specificity apart from the fact that some plants have more 
than one active principle responsible for their biological property. Hence an investigation was conducted to study the effect of extracts from few important medicinal plants against few phytobacteria.

\section{Materials and Methods}

\section{Selection of medicinal plants}

Medicinal plants mentioned in table 1 which were reported to contain some antibacterial constituents and being used in Indian system of medicine (Kamala Ramachandran et al., 1986) were selected to screen for their antibacterial properties against three important plant pathogenc bacteria causing serious diseases of vegetable crops. These plants were collected from College of Agriculture, Mandya.

\section{Isolation of pathogens}

The three important plant pathogenic bacteria viz., Ralstonia solanacearum, causal agent of tomato wilt, Xanthomonas axonopodis pv. vignicola causing bacterial blight of cowpea and Xanthomonas campestris pv. campestris causing black rot of cabbage were isolated from infected plants.

Tomato plants showing typical symptoms of vascular discolouration caused by $R$. solanacearum were collected. The presence of the pathogen in the host was confirmed by ooze test. The bacterium was isolated on solidified triphenyl tetrazolium chloride (TZC) agar medium (Kelman, 1954). The tissue from the lower part of the infected stem were cut into small pieces aseptically, and surface sterilized in 70 percent alcohol and were washed in three series of sterile water to remove traces of alcohol. The infected tissue pieces were then suspended in a test tube containing sterilized water for 10 minutes. The bacterial suspension was spread on the surface of TZC medium with spreader. The inoculated plates were incubated at $30^{\circ} \mathrm{C}$ for 48 hours. The plates were observed for the development of wellseparated virulent colonies. It was purified by picking the highly virulent colonies and streaked on the surface of TZC medium contained in Petri dishes. Three to four loopful of well-separated virulent colonies were suspended in sterile distilled water taken in vials. The vials were stored at $5^{\circ} \mathrm{C}$, and served as stock culture for further studies.

Similarly cowpea leaves showing bacterial blight symptom and cabbage leaves with black rot symptom were collected, surface sterilized. The bits were suspended in a drop of sterile water. A loopful of the bacterial suspension was taken on an inoculation needle aseptically and streaked on the surface of solidified nutrient agar medium.

The inoculated plates were incubated at $28^{\circ} \mathrm{C}$ for 48 hours and were observed for the development of well-separated typical Xanthomonas colonies and well grown colonies are selected for purification. Similarly they were stored at $5^{0} \mathrm{C}$ for further studies. The three bacteria isolated from diseased plants were identified on the basis of morphological, cultural and biochemical characteristics prescribed by Bradbury (1986) and Schaad and Stall (1998).

\section{Method of Extraction}

Two most common methods used in extraction were followed to extract the antimicrobial components contained in four different plant species in order to screen for their antimicrobial property against the most common and serious phytopathogenic bacteria were (1) Water extract method (2) Alcohol extract method.

\section{Protocol for water extract}

The shoot and leaves constituting economic parts of the plants noted in table 1 were used for the purpose of extraction. $50 \mathrm{~g}$ of leaves or seed as the case may be were taken and cut into small pieces under aseptic condition. The sample was put into waring blender containing $50 \mathrm{ml}$ sterilized distilled water at a ratio 1:1 (water: plant material). The sample was spun at low speed for 10-15 minutes in a coffee warring blender till the material formed to fine texture. The blended material was then squeezed through a sterilized muslin cloth so as to get a crude liquid extract. The crude extract was filtered through Whatman no 1 filter paper followed by sterilized Seitz filter. The sterilized filterate was collected in sterilized glass tubes and the tubes were sealed under aseptic condition and 
labelled as "WE". The water extract was kept at $5^{\circ} \mathrm{C}$ in a refrigerator for further use.

\section{Protocol for alcohol extract}

Fifty gram of the economic parts of the respective plant was mixed with a small quantity of 70 per cent ethyl alcohol and macerated in a pestle and morter under aseptic condition. The material was blend to fine texture, transferred to a beaker and the final volume was made up to $50 \mathrm{ml}$ with 70 per cent ethyl alcohol in the ration of 1:1 (plant material: alcohol). The beaker was kept overnight under refrigerated condition. Alcohol extract was squeezed through muslin cloth, then passed and finally sterilized through Seitz filter apparatus. The sterilized filterate was collected in sterilized glass tubes and the tubes were sealed under aseptic condition and labelled as "AE". The alcoholic extract was stored at $5^{\circ} \mathrm{C}$ in a refrigerator for further use.

\section{In-vitro evaluation of plant extracts}

Both water and alcohol extracts of the four medicinal plants were screened at different dilutions viz., 1:0 (undiluted), 1:1, 1:10, 1:100, 1:1000. The efficacy of the extracts were tested by the zone of inhibition assay technique against the following bacterial plant pathogens known to cause serious diseases of vegetable crops viz., Ralstonia solanacearum causing bacterial wilt of tomato, Xanthomonas axonopodispv. vignicola causing bacterial blight of cowpea and Xanthomonas campestris pv. campestris causing black rot of cabbage.

\section{Inhibition zone technique}

The effect of extracts obtained from economic parts of different plants was tested by inhibition zone technique at different dilutions of the extract. A heavy suspension of the test bacteria $\left(7 \times 10^{8} \mathrm{cfu} / \mathrm{ml}\right)$ was seeded to the sterilized nutrient agar medium by mixing the bacterial cultural with the cooled nutrient agar $\left(45-50^{\circ} \mathrm{c}\right)$ in a $500 \mathrm{ml}$ Erylenmeyer flask. The seeded medium was poured on sterilized Petri plates and allowed to solidify.

Sterilized filter paper disc (Whatman no.1) measuring $10 \mathrm{~mm}$ diameter were soaked for 10 minutes in undiluted (1:10) and diluted (1:1, 1:10, $1: 100$ and $1: 1000)$ plant extracts and placed on the surface of seeded nutrient agar medium contained in the Petri plates in marked position. The inoculated plates were incubated first at $4^{\circ} \mathrm{C}$ for 4 hours so as to allow the diffusion of the extract into the medium. The plates were then transferred to incubator maintained at $30^{\circ} \mathrm{C}$ and incubated for 48 hours. Observations were recorded on the zone of inhibition produced around the filter paper disc in each plant extract at different dilutions, by measuring the diameter of the inhibition zone.

\section{Results and Discussion}

\section{Effect of Ocimum gratissiumum extract}

The results of the experiments conducted on efficacy of water and alcohol extracts obtained from the four medicinal plants were investigated for their effect on the growth of $R$. solanacearum causing bacterial wilt of tomato, $X$. axonopodis pv. vignicola and $X$. campestris pv. camperstris causing bacterial blight of cowpea by inhibition zone assay technique under in-vitro conditions. Water extract of $O$. gratissimum produced inhibition zones of 28.66, 26.66 and $22.66 \mathrm{~mm}$ at $1: 10,1: 1$ and $1: 10$ dilutions respectively but could not produce any zone at 1:100 and 1:1000 dilution against $R$. solanacearum, whereas, alcohol extract of $O$. gratissimum produced inhibition zones of $29.66,28.33$, and 19.33 at $1: 1,1: 10$ and $1: 100$ dilution respectively but no inhibition zone was produced at 1:1000 dilution. The water extract of $O$. gratissimum against the $X$. axonopodis pv. vignicola induced the inhibition of $28.33,25.00$ and $21.66 \mathrm{~mm}$ at $1: 0,1: 1$ and $1: 10$ dilutions respectively but could not inhibit the growth of $X$. $a$. pv. vignicola at 1:100 and 1;1000 dilution, whereas, alcohol extract produced inhibition zones of $30.33,28.66$, and 20.33 at 1:0, 1:1, 1:10 and 1:100 dilutions respectively but it could not produce any inhibition zone at 1:1000 dilution (Table 2). Further, effect on $X$. campestris pv. campestris water extract of $O$. gratissum produced inhibition zones of $29.33,24.33$ and $22.33 \mathrm{~mm}$ at 1:0, 1:1 and 1:10 dilutions respectively but could produce any zones at 1:100 and 1:1000 dilution against $X$. campestris pv. campestris. Whereas alcohol extract produced inhibition zones. Both the water and alcohol extract of Ocimum gratissimum was found to be effective in 
inhibiting the growth of three phytopathogenic bacteria tested. Similar inhibitory activity of $O$. gratissimum extract was observed by Rodriguez et al., (1997), Saha et al., (2013) and Mishra et al., (2015) against few bacteria and fungi tested.

\section{Effect of Ocimum sanctum extract}

In the present investigation it was found that alcohol extract of Ocimum sanctum was potent in inhibiting the growth of all the three phytopoathogenic bacteria viz., Ralstonia solamacearum, Xanthomonas axonopodis pv. vignicola and $X$. campestris pv. campestris upto dilution of 1:10. However, the extract was found to possess highly significant activity at $1: 1$ dilution and produced an inhibition zone of 20.3, 18.33 and $19.33 \mathrm{~mm}$ respectively as compared to $14.33,14.00$ and $15.66 \mathrm{~mm}$ inhibition zone noticed in streptocycline at 400ppm which is used as standard check (Table 3). Even at dilution of 1:10 a significant inhibitory zone in all the three bacterial pathogen was noticed.

However, the water extract was not at all inhibitory as no inhibition zone was obtained against all the three bacteria probably the antimicrobial component eugenol, caryophyllence and methyleugenol might not have been eluded. Rajendhran et al., (1998) observed that extract of $O$. sanctum was very effective against both Grampositive and Gram-negative bacteria viz: Staphylococcus aureus, E. Coli, Pseudomonas aeruginosa and Klebsiella spp. Wood et al., (1997), Citoglu et al., (1998) and Saha et al., (2013) reported inhibitory effect of medicinal plant extracts against Gram-positive and Gramnegative bacteria and few plant pathogenic fungi. Solvent extracts of Ocimum sanctum showed inhibited the growth of $R$. solanacearum (Murthy et al., 2014).

\section{Effect of Tylophora asthmatica extract}

Water extract of another medicinal plant $T$. asthmatica produced an inhibition zone of 17.33 and $13.33 \mathrm{~mm}$ diameter at $1: 0$ and 1:1 dilution respectively but could not produce any zones at higher dilution viz, 1:10, 1:100 and 1:1000 against $R$. solanacearum. Whereas, alcohol extract produced inhibition zones of 19.33, 15.66 and $12.33 \mathrm{~mm}$ diameter at 1:0,1:1 and 1:10 dilutions respectively but not at 1:100 and 1:1000 dilutions. Streptocycline at $400 \mathrm{ppm}$ produced an inhibition zone of $14.33 \mathrm{~mm}$ diameter.

Water extract of Tylophora asthmatica on X. axonopodis pv. vignicola produced an inhibition zones of 18.33 and $14.33 \mathrm{~mm}$ diameter at 1:0 and 1:1 dilution respectively but could not produce any zones at higher dilution viz, 1:10, 1:100 and 1:1000 against $X$. axonopodis pv. vignicola, whereas, alcohol extract produced inhibition zones of $19.66,16.66$ and $13.33 \mathrm{~mm}$ diameter at 1:0, 1:1 and 1:10 dilutions respectively, but no inhibition zone was observed at 1:100 and 1:1000 dilutions (Table 4). Streptocycline at 400ppm used as standard check produced an inhibition zone of $14.00 \mathrm{~mm}$ diameter.

Water extract of $T$. asthmatica on $X$. campestris pv. campestris produced an inhibition zones of 24.33 and 23.00 and $18.66 \mathrm{~mm}$ diameter at 1:0, 1:1 1nd 1:10 dilution respectively but not at higher dilution of 1:100 and 1:1000 against $X$. campestris pv. campestris, whereas, alcohol extract produced an inhibition zones of 25.33, 23.33 and $19.66 \mathrm{~mm}$ at 1:0, 1:1, and 1:10 dilutions respectively but could not produce any zones at 1:100 and 1:1000 dilutions. While, streptocycline at $400 \mathrm{ppm}$ produced an inhibition zone of $15.66 \mathrm{~mm}$ diameter.

Table.1 List of medicinal plants containing antimicrobial constituents and economic parts used for screening against phytopathogenic bacteria

\begin{tabular}{|l|l|l|l|l|}
\hline Sl.No & Common Name & Scientific Name & Family & Parts used \\
\hline 1 & Holy basil & Ocimum sanctum L. & Lamiaceae & Leaves \\
\hline 2 & Clocimum & Ocimum gratissimum L. & Lamiaceae & Leaves \\
\hline 3 & Antamul & Typlophora asthmatic W.\& A. & Asclepiadaceae & Leaves \\
\hline 4 & Garden Rue & Ruta graveolens L. & Rutaceae & Shoot \\
\hline
\end{tabular}


Int.J.Curr.Microbiol.App.Sci (2017) 6(10): 2825-2831

Table.2 Effect of Ocimum gratissimum extracts against three phytopathogenic bacteria

\begin{tabular}{|c|c|c|c|c|c|c|c|}
\hline \multicolumn{8}{|c|}{ Diameter of inhibition zone (mm) } \\
\hline \multicolumn{3}{|c|}{ Water extract } & \multicolumn{5}{|c|}{ Alcohol extract } \\
\hline Dilution & R. solanacearum & $\begin{array}{l}\text { X. axonopodis } \\
\text { pv. vignicola }\end{array}$ & $\begin{array}{l}\text { X. campestris } \\
\text { pv. campestris }\end{array}$ & R. soland & cearum & $\begin{array}{c}\text { X. axonopodis } \\
\text { pv. vignicola }\end{array}$ & $\begin{array}{l}\text { X. campestris } \\
\text { pv. campestris }\end{array}$ \\
\hline $1: 0$ & $28.66(5.45)$ & $28.33(5.42)$ & $29.33(5.51)$ & $29.66(5.5$ & & $30.33(5.60)$ & $31.66(5.71)$ \\
\hline $1: 1$ & $26.66(5.26)$ & $25.00(5.10)$ & $24.33(5.03)$ & $28.33(5.4$ & & $28.66(5.45)$ & $26.33(5.23)$ \\
\hline $1: 10$ & $22.66(4.86)$ & $21.66(4.76)$ & $22.33(4.83)$ & $24.33(5.0$ & & $25.66(5.16)$ & $22.00(4.79)$ \\
\hline $1: 100$ & $0.00(1.00)$ & $0.00(1.00)$ & $0.00(1.00)$ & $19.33(4.5$ & & $20.33(4.62)$ & $18.66(4.43)$ \\
\hline $1: 1000$ & $0.00(1.00)$ & $0.00(1.00)$ & $0.00(1.00)$ & $0.00(1.00$ & & $0.00(1.00)$ & $0.00(1.00)$ \\
\hline $\begin{array}{l}\text { Streptocyclive } 400 \mathrm{ppm} \text {. } \\
\text { (control) }\end{array}$ & $14.33(3.92)$ & $14.00(3.87)$ & $15.66(4.08)$ & $14.33(3.9$ & & $14.00(3.87)$ & $15.66(4.08)$ \\
\hline & & \multicolumn{3}{|l|}{ S.Em+ } & \multicolumn{3}{|c|}{$\mathrm{CD}(1 \%)$} \\
\hline Factor A & & \multicolumn{3}{|l|}{0.0197} & \multicolumn{3}{|l|}{0.0556} \\
\hline Factor B & & \multicolumn{3}{|l|}{0.0197} & \multicolumn{3}{|l|}{\begin{tabular}{|l|}
0.0556 \\
\end{tabular}} \\
\hline$A \times B$ & & \multicolumn{3}{|l|}{0.0483} & \multicolumn{3}{|l|}{0.1362} \\
\hline
\end{tabular}

*Figures in parenthesis are square root transformed values

Table.3 Effect of Ocimum sanctum extracts against three phytopathogenic bacteria

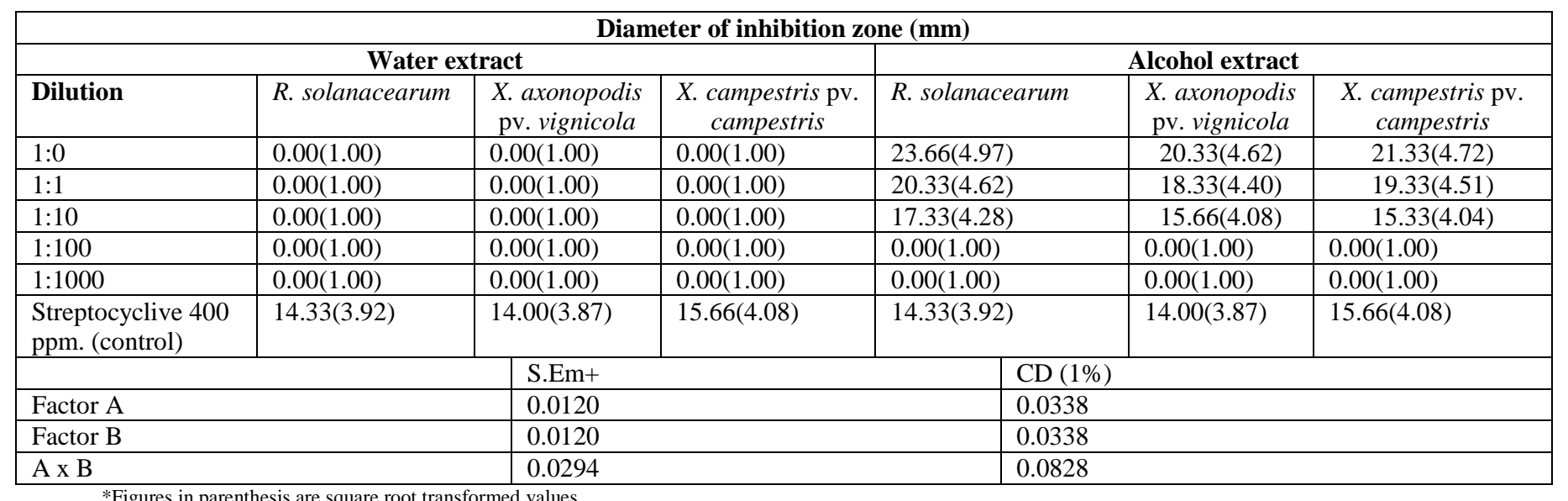

Table.4 Effect of Tylophora asthmatica extracts against three phytopathogenic bacteria

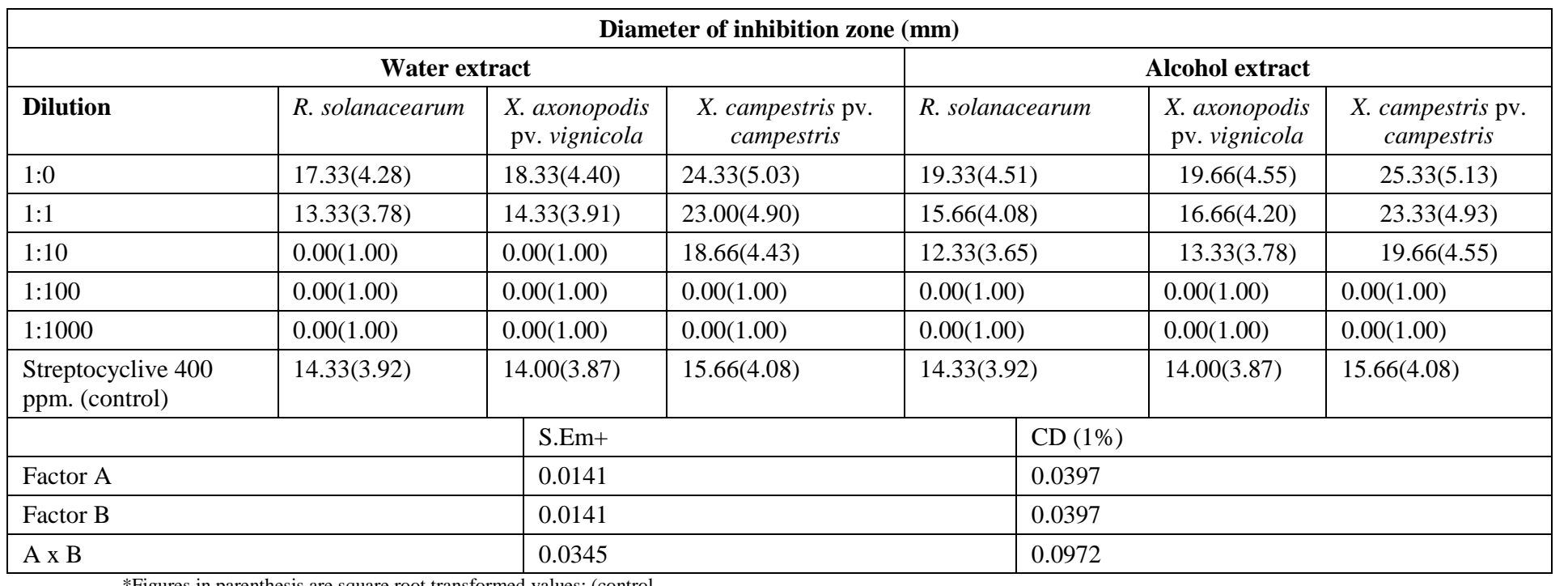

*Figures in parenthesis are square root transformed values; (control- 
Int.J.Curr.Microbiol.App.Sci (2017) 6(10): 2825-2831

Table.5 Effect of Ruta graveolens extracts against three phytopathogenic bacteria

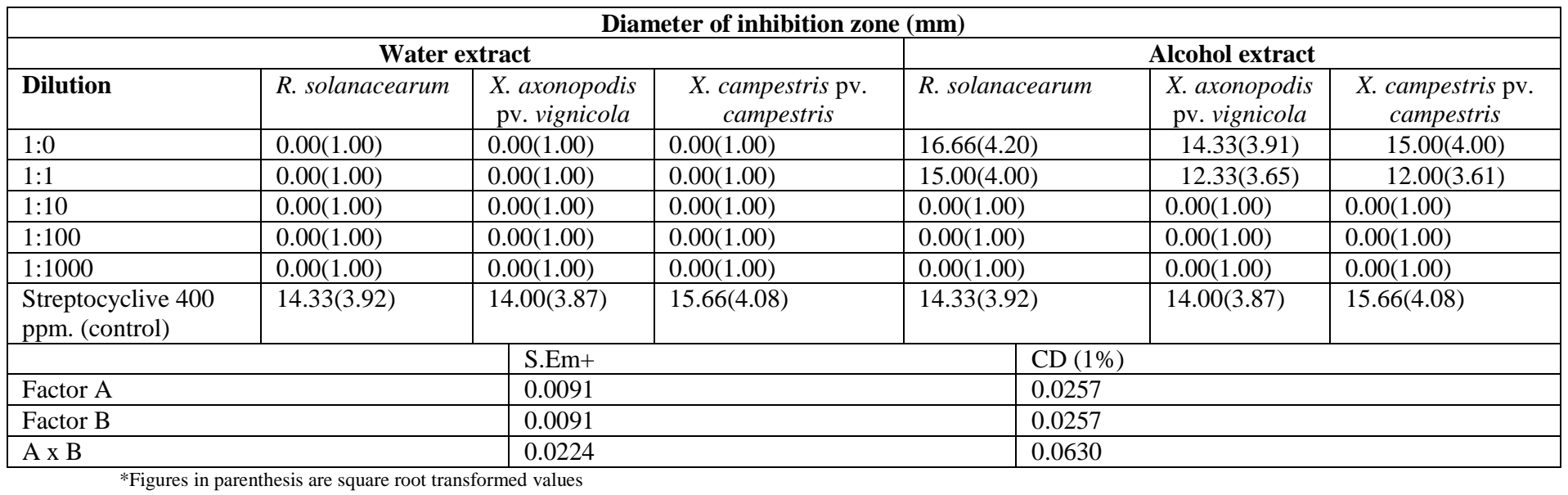

The water and alcohol extracts of Tylophora asthmatica were found to be effective in inhibiting the growth of all the three phytopathogenic bacteria tested. Similar results regarding inhibitory activity in plant extract of Cryptostegia grandiflora belonging to family Asclepiadaceae to which $T$. asthmatica also belongs was observed by Mukherjee et al., (1999) against few bacteria viz, Pseudomonas cepacia, Bacillus megatorium, B. subtilis, B. coagulans, Staphylococcus aureus and E. coli. Similarly, Ponnanikajamideen et al., (2013) found that $T$. asthmatica extracts obtained from different extracts showed inhibitory effect against different strains of bacteria.

\section{Effect of Ruta graveolens extract}

The alcohol extract of Ruta graveolens root was found to be effective whereas, water extract was ineffective in inhibiting the growth of all the three phytopathogenic bacteria tested. The alcohol extract produced an inhibition zone of 16.66 and $15.00 \mathrm{~mm}$ diameter at $1: 0$ and $1: 1$ dilutions respectively against $\mathrm{R}$. solanacearum, but could not produce any zone at 1:10, 1:100 and 1:1000 dilutions. While, streptocyclineat 400ppm, produced an inhibition zone of $14.33 \mathrm{~mm}$ diameter (Table 5).

The alcohol extract effect of Ruta graveolens against $X$. axonopodis pv. vignicola produced an inhibition zone of 14.33 and $12.33 \mathrm{~mm}$ diameter at 1:0, 1:1 dilution respectively but could not produce any inhibition zone at higher dilutions of
1:10, 1:100 and 1:1000. Streptocycline at 400ppm produced an inhibition zone of $14.00 \mathrm{~mm}$ diameter. Finally, the water extract of Ruta graveolens was found to be ineffective in inhibiting the growth of $X$. campestris pv. campestris. Whereas alcohol extract produced an inhibition zone of 15.00 and $12.00 \mathrm{~mm}$ diameter at $1: 0$ and $1: 1$ dilutions respectively but not at 1:10, $1: 100$ and 1:1000 dilutions. Streptocycline at 400ppm produced an inhibition zone of $15.66 \mathrm{~mm}$ diameter. Zobel et al., (1997) found that leaf extract of $R$. graveolens retarded the mitosis activity and they attributed that probably it was due to presence of xanthotoxin and psoralens. The alcohol and water extracts of $R$. graveolens exhibited inhibitory activity against many Gram negative bacterial and plant pathogenic fungi tested (Pandey et al., 2011). The present investigation revealed the antimicrobial nature of the extracts of medicinal plant tested. Hence these could be exploited as an alternate management strategy for chemical pesticides as they are ecofriendly and safe. The future studies should focus on identification and elucidation of the active principles present in medicinal plants having potential antimicrobial properties.

\section{References}

Bradbury, J.F., 1986, Guide of Plant Pathogenic Bacteria. CAB, International Mycological Institute, Kew, Survey, England, pp. 332.

Citoglu, G., Tanker, M., Sever, B., Englert, J., Anton, R. and Atlanlar, N., 1998, Antibacterial activities of diterpenoids 
isolated from Ballotasaxatilis var. saxatilis. PlantaMedica, 64: 484-485.

Kamala Ramachandran, Kashyapa, K. And Ramesh Chand, 1986. The useful plants of India. Publication and Information Directorate, CSIR, New Delhi, pp. 918.

Mishra, R.P., and Javed, I., 2015, Invito activity of medicinal plants against some bacterial and fungal isolates.Asian J. Pharm. Clin. Res., 8(1): 225-230.

Mukherjee, P.K., Gunasekharan, R., Subburaju, T., Dhanbal, S.P., Duraiswamy, B., Vijayan, P. and Suresh, B., 1999, Studies on the antibacterial potential of Cryptostegiagrandiflora $\mathrm{R}$. Br. Phytotherapy Research, 13: 70-72.

Murthy, K.N., Nagendra, K., Uzma, F., Sowmya, K. and Srinivas, C., 2014, Efficiency of Ocimum sanctum L. leaf extract against bacterial wilt of tomato caused by Ralstonia solanacearum in tomato. Int. J. Curr. Microbiol. App. Sci., 3(12): 234-245.

Pandey, P., Mehta, A. and Hajra, S., 2011, Evaluation of antimicrobial activity of Rutagraveolens stem extracts by disc diffusion method. J. Phytol. 3(3): 92-95.

Ponnanikarjamideen, M., Selvamaleeswaran, P. and Annadurai, G., 2013, Antibacterial activity of solvent extracts of Tylophoraasthmatica (leaves) against different bacterial strains. Int. J. Res. Bot., 3(1): 13-18.
Rajendran, J., Arun Mani, M. and NavaneethaKannan, K., 1998, Antimicrobial activity of some selected medicinal plants. Geobios, 25: 280-282.

Rodiguez, R., Garcia, M. Pino, J. And Hernandez, L., 1997, In-vitro antimicrobial activity of medicinal species of the Cuban flora. International joint symposium: Chemistry, Biological and Pharmacological properties of medicinal plants from the Americas, Panama, Republic of Panama, A-17, February 23-26.

Saha, S., Dhar, T.N., Sengupta, C. and Ghosh, P., 2013, Biological activities of essential oils and methonal extracts of five Ocimum species against pathogenic bacteria. Czech J. Food Sci., 31(2): 194-202.

Schaad, N.W., and Stall, R.E., 1988, Laboratory Guide for Identification of Plant Pathogenic bacteria, $2^{\text {nd }}$ Ed. American Phytopath. Soc., pp. 138.

Wood, M., Schollenberger, M. and Zamorski, C., 1997, Effects of extracts of four medicinal plants on growth of selected fungi and bacteria. Annals of Warsaw Agricultural University S.G.G.M., Horticulture, 18: 41-52.

Zobel, A.M., Lynch, J.M., Murphy, K.E. and Wierzowska- Renke, K., 1997, Difference in antimitotic activity of natural products removed from plant surface and interior of Ruta graveolens L. and Brassica oleracea L. Herba Polonica, 43: 334-337.

\section{How to cite this article:}

Kiran Kumar N., V. B. Sanath Kumar, H. R. Raveendra and Manjunatha S. E. 2017. Potentiality of Extracts of Medicinal Plants against Important Plant Pathogenic Bacteria. Int.J.Curr.Microbiol.App.Sci. 6(10): 2825-2831 doi: https://doi.org/10.20546/ijcmas.2017.610.331 